\title{
Climate Influences Vegetative and Reproductive Components of Primocane-fruiting Red Raspberry Cultivars
}

\author{
Jean-Pierre Privé ${ }^{\prime}$ J.A. Sullivan, J.T.A. Proctor, and O.B. Allen ${ }^{2}$ \\ Department of Horticultural Science, University of Guelph, Guelph, Ont., N1G 2W1, Canada \\ Additional index words. autumn-bearing, fall-bearing, genotype $\times$ environment, Rubus idaeus
}

\begin{abstract}
Climatic elements (solar radiation, daylength, water supply, growing degree days (GDD), corn heat units (CHU), soil, and air temperatures) were monitored to determine which elements could account for the variability in yield of primocane-fruiting red raspberry (Rubus idaeus L.) cultivars. The climatic elements were classed as either having a major or minor influence on the vegetative and reproductive components, based on the frequency of the significance of the multiple regression coefficients. Soil temperature and water supply had a major influence, while daylength, solar radiation, and aboveground temperature (i.e., air, GDD, or CHU) had a lesser influence on these components. Soil temperature had the largest influence during April and May, while water supply was equally influential at all times during the season. Air temperature and solar radiation had their largest influence during the period of flower initiation and development (i.e., June and July), while daylength was most influential from June to October. Berry count, weight, and yield had the highest frequency of associations among the climatic elements, indicating the complexity of the association between these yield components and climate. Total number of nodes/cane, length of the fruiting section/cane, and the harvest period showed the fewest number of associations. Not all cultivars responded similarly to changes in their yield components. 'Autumn Bliss' was less sensitive to climatic variation than either 'Heritage' or 'Redwing'. When 'Redwing' was the anomaly, it was usually related to air or soil temperatures.
\end{abstract}

Genotype $\times$ environment interactions pose important problems in developing and selecting new cultivars for production in a wide range of environments. This is true of primocane-fruiting $(\mathrm{PF})$ red raspberries as the $\mathrm{PF}$ habit is under complex genetic control (Keep, 1988) and is significantly influenced by temperature, daylength, and the length of the growing season (Hoover et al., 1989). These authors reported that first and peak harvests differed between environments for 'Heritage' and 'Redwing'. In New York $\left(43^{\circ} \mathrm{N}\right)$, 'Heritage' began production 1 week earlier than 'Redwing', while in Mimesota $\left(45^{\circ} \mathrm{N}\right)$ and Michigan $\left(42.5^{\circ} \mathrm{N}\right)$, 'Redwing' was later by 1 and 2 weeks, respectively. No differences in first harvest dates were reported in Ontario $\left(43^{\circ} \mathrm{N}\right)$ or British Columbia $\left(49^{\circ} \mathrm{N}\right)$. Hoover et al. (1989) could not explain the differences between cultivar harvest dates based on heat unit accumulation or latitude. However, this lack of fit maybe due to using data from varying number of years at each site since it is likely that latitude (i.e., daylength) and heat unit accumulation do play an important role in determining dates of flowering and harvest.

The performance of British and Pacific Northwest summerbearing red raspberry cultivars when grown in Scotland and British Columbia also appears to be determined by the plant's genetics and how it is expressed in each environment (Dale and Daubeny, 1985). Productivity of red raspberries is intimately controlled by both the aboveground and belowground environment (Dale, 1989). In a review of the effects of the environment on the yield compo-

Received for publication 7 Oct. 1992. Accepted for publication 30 Oct. 1992 Financial assistance from Agriculture Canada to J-P.P. while on educational leave is gratefully acknowledged. This study was also supported by the Ontario Ministry of Agriculture and Food and the Ontario Berry Grower's Association. We thank T. Leuty (Harrow), A. Vandenberg (Vineland), S. Van Schyndel (Cambridge), J. Morton (Kemptville), M. Lamarre (Lavaltrie), and B. Hughes (New Liskeard) for their assistance with the yield trials. The cost of publishing this paper was defrayed in part by the payment of page charges. Under postal regulations, this paper therefore must be hereby marked advertisement solely to indicate this fact

'Corresponding author. Present address: Research Station, Agriculture Canada, P.O. Box 667, Bouctouche, N. B., E0A 1G0, Canada.

${ }^{2}$ Dept. of Mathematics and Statistics. nents of summer-bearing red raspberries, climatic effects on cane height and diameter determined the yield potential of the overwintering canes (Dale, 1986). In the 2nd year, climate influenced the growth of the fruiting laterals and determined the expression of the number of fruits at a lateral node. Fruit size was controlled by climate in the fruiting year only, as ovule count was similar and drupelet set and size varied in various environments. The influence of genotype $\times$ environment interactions on the performance of 'Autumn Bliss', 'Heritage', and 'Redwing' PF red raspberry cultivars has been reported for six sites across Ontario and Québec during 1989 and 1990 (Privé et al., 1993). No studies have examined the relationships between yield components and individual climatic factors in PF red raspberries.

The objectives of this study were to determine 1) whether variation in the yield components is attributable to the climatic elements and 2) which climatic elements most influence vegetative and reproductive development.

Materials and Methods

Data for three cultivars, six locations, and 2 years were used for this analysis because of the observed differences in performance previously reported (Privé et al., 1993). From that study, cultivar $\times$ location $\times$ year interactions were found for most vegetative and reproductive components analyzed, thus permitting determination of whether variation in these components could be attributable to the climatic elements. The design, data collection, and performance of the vegetative and reproductive components are given in Privé et al. (1993). In 1988, all locations were chosen at research institutions so that the plots would be near a climatological station (maximum distance $0.5 \mathrm{~km}$ ). The information from these stations provided the basis for the meteorological database for the study.

Climatic elements measured at each location in 1989 and 1990

Abbreviations: $\mathrm{CHU}$, corn heat units; GDD, growing degree days; PF, primocane fruiting. 
from 1 Apr. until the end of harvest included: air temperature $(C$; shielded thermistor $1.25 \mathrm{~m}$ above ground level), soil temperature at $10 \mathrm{~cm}$ under sod $(\mathrm{C})$, combined precipitation and irrigation $(\mathrm{mm}$ hereafter called water), and daylength (hours). Accumulated GDD and the number of Ontario CHU (Brown, 1978) were calculated from air temperature data. Solar radiation $\left(\mathrm{MJ} \cdot \mathrm{m}^{-2}\right)$ was calculated from bright sunshine hours using the methods described by Selirio et al. (1971). The climatic data were cumulated for the entire growing season, i.e., 1 Apr. to the end of harvest (ApO) and separated into three additional time intervals for further analysis: 1 Apr. to 31 May (ApM), 1 June to 31 July (JnJl), and 1 Aug. to end of harvest (Ago). These additional time intervals were chosen to determine the influence of the climatic factors on each of the yield components at a particular time of the season.

Statistical analysis. Regression techniques were used 1) to determine the overall importance of the 28 climatic elements in predicting each of the 13 vegetative and reproductive components and 2) to calculate, for each of the three cultivars, multiple regression equations relating each of the 13 vegetative and reproductive characteristics to the most significant climatic elements. For each reproductive and vegetative component in 1), an analysis of covariance was performed for each climatic element including cultivar. For 2), since there were only 12 environment; observed ( 2 years by six locations), not all climatic variables could not be simultaneously fitted in a multiple regression. Therefore the 28 climatic variables were fitted in six groups for five preliminary multiple regressions. The significant climatic variables from each of the five preliminary regressions were then fitted in a final multiple regression. The multiple regression models initially fitted a different slope for each cultivar. When the slopes proved to be similar across the three cultivars for a particular climatic variable, a single common slope was fitted.

In the analysis of variance corresponding to the initial model (Table 1), $\mathrm{Cl}_{1}$ represents the variation explained by fitting a common slope to climate variable 1 , and $\mathrm{Cl} \times$ cultivar represents the additional variation explained by allowing the slopes to differ across cultivars. The remaining $5 \mathrm{df}$ from environments was used to test the common slope for each weather variable and the remaining $10 \mathrm{df}$ from the environment $\times$ cultivar interaction was used to assess the differences in slopes among the three cultivars These models were fitted using the general linear models (GLM) procedure in SAS/STAT (SAS, 1987).

\section{Results}

Each of the 13 vegetative and reproductive components were regressed on the 28 climatic elements. The overall importance of each climatic component was determined by the number of times it was significant in the 13 regression equations (Table 2). The actual values of these multiple regression coefficients are given in Tables 3 and 4. Several climatic elements, such as air temperatures total number of GDD and CHU, had no significant effect on any of the vegetative or reproductive components when cumulated over the entire season (Table 2). However, when the growing season was divided into three calendar intervals, air temperature GDD and CHU had a positive effect on some of the vegetative and reproductive components. The two most influential climatic groups were soil temperature and water. Air temperature, GDD, CHU, solar radiation, and daylength were also important but significant for fewer vegetative and reproductive components

Soil temperature from the beginning of April 'to the end of harvest $(\mathrm{ApO})$ was significant for nine of the 13 vegetative and reproductive components, making it the most influential climatic component of the group (Table 2). Higher soil temperatures cumulated over the entire growing season (ApO) either had a positive influence (i.e., on cane height, berry count, and yield) negative influence (i.e., on date of first harvest and number of fruiting laterals), or had mixed effects (among cultivars) on cane diameter, flower count either per cane or per fruiting lateral and berry weight. When the growing season was divided into three intervals, soil temperature for the 8 weeks from 1 Apr. to 31 May was positively associated with six of the 13 components more than during any other interval of the season. Cultivar $\times$ soil temperature interactions were found for cane height, diameter, berry count and weight, and yield (Table 2). Of the three cultivars, cane height for 'Autumn Bliss' increased the least $\left(b_{1}=0.5\right)$, while cane diameter for 'Redwing' was reduced the most $(b,=4.0047)$ in response to higher soil temperatures when cumulated over the growing season (ApO) (Table 3): Higher soil temperatures (ApO) increased yields for 'Redwing' $(b=6.1)$ and 'Heritage' $(b=6.8)$ and to a lesser extent for 'Autumn Bliss' ( $b=1.8$ ) (Table 4).

The amount of water received over the entire growing season and especially from June to July, influenced several of the vegetative and reproductive components. Except for the date of first harvest for 'Heritage' and the harvest interval for 'Autumn Bliss' all growth and yield components increased with the amount of water received (Tables 2-4). Increasing the amount of water during June and July advanced the date of first harvest for 'Heritage' $\left(b_{2}=-0.006\right.$; a negative coefficient indicates that increasing water leads to an earlier date of first harvest) while delaying it for 'Autumn Bliss' $\left(b_{2}=0.025\right)$ and 'Redwing' $\left(b_{2}=0.016\right)$ (Table 3) The harvest period was longer for 'Heritage' and 'Redwing' $\left(b_{1}=\right.$ $0.03, b_{1}=0.01$, respectively), while it was shorter for 'Autumn Bliss' $\left(b_{1}=-0.01\right)$ when more water was received during June and July (Table 3). During the period of flower initiation and development (June and July), an increased supply of water gave positive increases in berry count, berry weight, and yield for all cultivars (Table 4). Of the three cultivars, berry count for 'Redwing' had the largest increase in response to water during June and July.

A comparison of the three methods of measuring aboveground temperature (i.e., average air temperature, GDD, or $\mathrm{CHU}$ ) re-

Table 1. An example of one of the five preliminary analysis of variance for yield components regressed on climatic $\left(\mathrm{Cl}_{n}\right)$ variables for three PF
raspberry cultivars.

\begin{tabular}{lc}
\hline Source & $\mathrm{df}$ \\
\hline Environment & 11 \\
$\mathrm{Cl}_{1}$ & 1 \\
$\mathrm{Cl}_{2}$ & 1 \\
$\mathrm{Cl}_{3}$ & 1 \\
$\mathrm{Cl}_{4}$ & 1 \\
$\mathrm{Cl}_{5}$ & 1 \\
$\mathrm{Cl}_{6}$ & 1 \\
Error & 1 \\
Cultivar & 5 \\
Environment $\times$ cultivar & \multicolumn{2}{c}{2} \\
$\mathrm{Cl}_{1} \times$ cultivar & 22 \\
$\mathrm{Cl}_{2} \times$ cultivar & 2 \\
$\mathrm{Cl}_{3} \times$ cultivar & 2 \\
$\mathrm{Cl}_{4} \times$ cultivar & 2 \\
$\mathrm{Cl}_{5} \times$ cultivar & 2 \\
$\mathrm{Cl}_{6} \times$ cultivar & 2 \\
Error & 2 \\
Total & 2 \\
& \multicolumn{2}{c}{2} \\
& \multicolumn{2}{c}{35} \\
\hline
\end{tabular}


vealed that no one method was superior. The aboveground temperature during the period from June to July positively influenced the greatest number of growth components (Table 2). Interactions between cultivars and aboveground temperature elements were found for flower count either per cane or per fruiting lateral, number of fruiting laterals, yield, berry count; and weight. The regression coefficients of total flower count per cane on $\mathrm{CHU}$ $(\mathrm{AgO})$ were positive for 'Heritage' $\left(\mathrm{b}_{4}=0.112\right)$ but small and negative for 'Redwing' $\left(b_{4}=-0.014\right)$ and 'Autumn Bliss' ( $b=$ 0.072) (Table 3). 'Heritage' is also the least precocious cultivar and, therefore, required a longer season to reach full yield potential. Subsequently, latitudes with higher CHU and solar radiation during June and July resulted in a greater increase in 'Heritage' berry weight than either 'Autumn Bliss' or 'Redwing' (Table 4).

Similar to aboveground temperature elements, solar radiation from June to July was a significant element for five of the 13 characters measured. However, unlike the previously discussed climatic elements, the most significant regression coefficients of yield components on solar radiation were negative (Table 2). For example, locations with higher cumulative solar radiation levels during April and May decreased the length of time required for flowering. However, higher levels of solar radiation during April and May delayed the date of first harvest for 'Heritage' $\left(b_{3}=0.079\right)$ and 'Autumn Bliss' $\left(b_{3}=0.003\right)$ while advancing it for 'Redwing' $\left(b_{3}=-0.045\right)$ (Table 3$)$. Interestingly, high solar radiation during June and July decreased berry count and yield but increased berry

Table 2. Indication of sign and cultivar $\times$ climate interactions for one variable regressions of yield components on the climatic elements.

\begin{tabular}{|c|c|c|c|c|c|c|c|c|c|c|c|c|c|c|}
\hline \multirow{3}{*}{$\begin{array}{l}\text { Climatic } \\
\text { element }^{2}\end{array}$} & & & \multirow{3}{*}{$\begin{array}{l}\text { Node } \\
\text { count/ } \\
\text { cane }\end{array}$} & \multirow{3}{*}{$\begin{array}{c}\text { Full } \\
\text { bloom }\end{array}$} & \multirow{3}{*}{$\begin{array}{l}\text { First } \\
\text { harv. }\end{array}$} & \multicolumn{2}{|c|}{ Flower count } & \multirow{3}{*}{$\begin{array}{c}\text { Fruit. } \\
\text { lat. } \\
\text { no. }\end{array}$} & \multirow{3}{*}{$\begin{array}{c}\text { Fruit. } \\
\text { sect. } \\
\text { length }\end{array}$} & \multirow[b]{3}{*}{ Yield } & & & \multirow{3}{*}{$\begin{array}{c}\text { Harv. } \\
\text { per. }\end{array}$} & \multirow[b]{3}{*}{ Frequency } \\
\hline & \multicolumn{2}{|c|}{ Cane } & & & & Per & Per & & & & & & & \\
\hline & $\mathrm{Ht}$ & $\overline{\text { Diam }}$ & & & & cane & lat. & & & & $\mathrm{Wt}$ & Count & & \\
\hline \multicolumn{15}{|l|}{ Soil temp } \\
\hline ApM & $+^{y}$ & & + & & & + & + & & & + & & + & & 6 \\
\hline JnJ1 & + & & - & & & & & & & & - & & & 2 \\
\hline AgO & + & & & & & & & & & & + & & & 2 \\
\hline ApO & $+\mathrm{cv}$ & $\pm c v$ & & & - & $\pm c v$ & $\pm c v$ & - & & $+\mathrm{cv}$ & $\pm c v$ & $+\mathrm{cv}$ & & 9 \\
\hline \multicolumn{15}{|l|}{ Air temp } \\
\hline ApM & & & & & & & & & & & + & & & 1 \\
\hline JnJ1 & & + & & & & $+\mathrm{cv}$ & $+\mathrm{cv}$ & + & & & & $+\mathrm{cv}$ & & 5 \\
\hline AgO & & & + & & & & & & & & & & + & 2 \\
\hline ApO & & & & & & & & & & & & & & 0 \\
\hline \multicolumn{15}{|l|}{ GDD } \\
\hline ApM & & & & & & & & + & & $+\mathrm{cv}$ & & $+\mathrm{cv}$ & & 1 \\
\hline JnJ1 & & + & & & & + & & + & & & & & & 5 \\
\hline $\mathrm{AgO}$ & & & & & & $+\mathrm{cv}$ & $+\mathrm{cv}$ & & & & & & & 2 \\
\hline $\mathrm{ApO}$ & & & & & & & & & & & & & & 0 \\
\hline \multicolumn{15}{|l|}{ CHU } \\
\hline ApM & & & & + & + & & & & & & & & & 2 \\
\hline JnJl & & + & & & & & & & & $+\mathrm{cv}$ & $+\mathrm{cv}$ & $+\mathrm{cv}$ & & 4 \\
\hline $\mathrm{AgO}$ & & & & & & $\pm c v$ & $+\mathrm{cv}$ & & & & & & & 2 \\
\hline $\mathrm{ApO}$ & & & & & & & & & & & & & & 0 \\
\hline \multicolumn{15}{|c|}{ Solar radiation } \\
\hline \multicolumn{14}{|l|}{2} & \\
\hline JnJ1 & & & & & & - & - & & & $-\mathrm{cv}$ & $+\mathrm{cv}$ & $-\mathrm{cv}$ & & 5 \\
\hline AgO & - & & & & & & & & & & & & + & 2 \\
\hline $\mathrm{ApO}$ & & & & - & & & & & - & & $+\mathrm{cv}$ & & & 3 \\
\hline Daylength & & & & & & & & & & & & & & \\
\hline ApM & & & & & + & & & & & & & & & 1 \\
\hline JnJl & & & & \pm & & & - & & & & $+\mathrm{cv}$ & $-\mathrm{cv}$ & & 4 \\
\hline AgO & + & $-c v$ & & & & & & - & + & & + & & & 5 \\
\hline ApO & & & & - & & & & & + & & + & & & 3 \\
\hline \multicolumn{15}{|l|}{ Water } \\
\hline ApM & & & & & $\pm c v$ & & & & & + & & $+\mathrm{cv}$ & & 3 \\
\hline JnJl & & & & & $\pm c v$ & & & $+\mathrm{cv}$ & & + & & $+c v$ & $\pm c v$ & 5 \\
\hline $\mathrm{AgO}$ & + & & & & $\pm c v$ & & & + & & + & & & & 4 \\
\hline $\mathrm{ApO}$ & + & + & & & & + & & + & & + & + & + & & 7 \\
\hline Frequency & 8 & 6 & 3 & 5 & 7 & 8 & 7 & 8 & 3 & 9 & 10 & 10 & 3 & \\
\hline
\end{tabular}

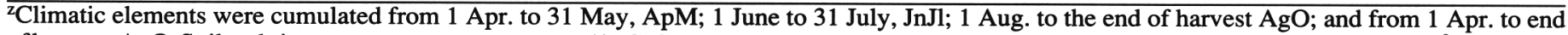

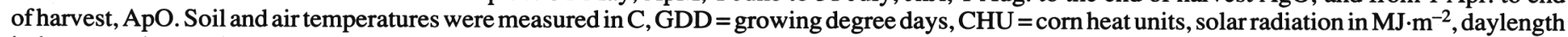
in hours, and water is the total amount of water received from precipitation and irrigation (millimeters).

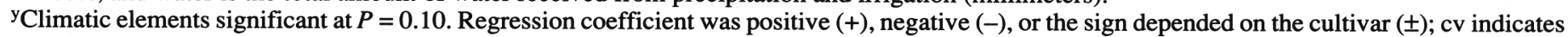

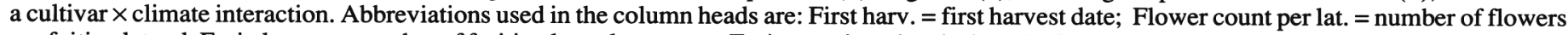

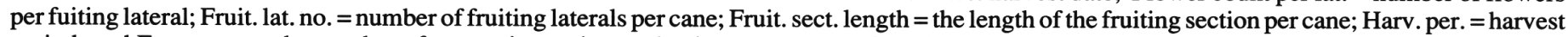
period; and Frequency = the number of vegetative and reproductive components for which the climatic variable is significant. 
weight for all cultivars (Table 4). Of the three cultivars, solar radiation during June and July decreased berry count and yield the most for 'Redwing' ( $b=-0.35$ and -0.44 , respectively). Although higher solar radiation levels during June and July had a positive influence on berry weight, there was a concomitant decrease in berry count and, hence, yields were also decreased by high solar radiation during this time interval.

Daylength, especially from June to July and from August to October, had a mixed influence on the vegetative and yield components (Table 2). Longer daylengths reduced cane diameters, dates of $\mathrm{FB}$, the flower count per fruiting lateral, number of fruiting laterals, and berry count. Cane height, the length of the fruiting section, and berry weight were increased when grown under longer daylengths (Table 2). Comparing the response of the three cultivars to longer daylengths, cane diameter for 'Redwing' decreased the most $\left(b_{3}=-0.049\right)$ (Table 3). Furthermore, date of FB was advanced for 'Autumn Bliss' and 'Redwing' $\left(b_{2}=-1.91\right.$ and -0.79 , respectively) but delayed for 'Heritage' $\left(b_{2}=0.38\right)$ (Table 3).

Based on the significance of the regression coefficients, berry count, weight, and yield had the highest frequency of associations with the climatic elements measured (-10). In contrast, node count per cane, length of the fruiting section, and the harvest period showed the fewest number of associations (about 3 ).

\section{Discussion}

Based on the frequency of the significance of the regression coefficients within the model, each climatic element was classed as having a major or minor influence on the vegetative and reproductive components. Soil temperatures and water had a major effect, while daylength, solarradiation, and aboveground temperature, i.e., air, GDD, or CHU, had a lesser role in influencing these components. However, cultivars responded differently to the climatic elements.

Nine of the 13 vegetative and reproductive components measured were significantly influenced by soil temperatures. Rajappan and Boynton (1960) stressed the importance of soil temperatures on growth of raspberry root systems. Higher root and shoot dry weights were obtained when soil temperatures were $<16 \mathrm{C}$, while higher soil temperatures inhibited growth and may be a limiting factor for red raspberry growth in warmer areas of the temperate zone. Erf (1987) found soil temperature to be one of the most important climatic factors, positively correlated to weekly trunk growth in apples (Malus domestica Borkh.). High soil temperatures during June and July were associated with a reduction in total node count. Although the number of nodes in red raspberry have been reported to be produced at a nearly constant rate in the United Kingdom, independent of environment (Jennings and Dale, 1982), it is possible that extremes in maximum daily temperatures in the present study could account for the observed differences. Soil and air temperatures during the summer months, in a maritime climate such as the United Kingdom, would not be as extreme as those found in central Canada and the northern United States, where summer air temperatures regularly exceed 35C.

Berry count and yield, especially for 'Heritage' and 'Redwing', were also increased in areas having higher cumulated soil temperatures over the entire growing season. 'Autumn Bliss' was influenced to a lesser degree. At no time was the beneficial effect of higher cumulated soil temperatures more evident than during April and May. For all cultivars, higher soil temperatures during April and May produced greater cane growth, more nodes, flowers, and berries, and a higher yield by the end of the growing season, but had little effect on advancing the dates of full bloom or first harvest. One explanation may be that air temperature usually has a greater effect on flowering than soil temperature (Kinet et al., 1985). Whether root growth was partially responsible for yield differences in the present study is unknown, although increased root growth in red raspberry has been positively associated with shoot growth and yield (Atkinson, 1973) or negatively associated with yield (Voroncihina, 1967).

The amount of water received during the entire growing season was the second most frequently significant climatic element, showing an increase in seven of the 13 measured components. In contrast to the other climatic elements, the amount of water received was equally influential at all times during the growing season, suggesting that water is important during all stages of development in PF red raspberries. Increased water availability over the entire growing season increased both the vegetative and reproductive components for all cultivars, while increased water during June and July influenced cultivars differently.

At locations with greater available water during the period of flower initiation and development (June and July), first harvest dates were earlier for 'Heritage' and later for 'Autumn Bliss' and 'Redwing', as we reported in Privé et al. (1993). We also found that berry count for 'Redwing' showed the greatest increase with additional water during this period. Irrigation also increased cane growth and yield of summer-bearing raspberries in southern England (Goode and Hyrycz, 1968) and in Norway (Kongsrud, 1969). Yield increases were either a result of berry weight (Goode and Hyrycz, 1968) or berry count and weight (Kongsrud, 1969). However in both studies, the yield increase due to irrigation was only significant during the drier years. The present study agrees with Goode and Hyrycz (1968) and Kongsrud (1969) that irrigation had a much greater effect in a "dry" year (1989) compared to a "wet" year (1990). The method by which soil water content influences reproductive development in PF red raspberries has been ignored by researchers (Dale, 1989). In many cereal crops, the water status of the soil has a marked influence on flower development (Kinet et al., 1985). These authors reported that the sensitivity of the apical meristem to drought is particularly high and that cessation of its activity is not uncommon after only one episode of water stress. Since cane growth and flowering are both largely dependent on apical bud development in PF red raspberries, and water was influential at all time intervals during the growing season, it is likely that water stress does have an influence on these developmental processes. Whether differences between cultivars exist in the sensitivity of their xylem conducting systems during the critical period of flower initiation and development remains to be tested.

Daylength, solar radiation, and aboveground temperature (air, GDD, and CHU) each significantly influenced four or five of the 13 components (not all the same yield components), with the greatest influence on the vegetative and reproductive components occurring during June and July. On average, higher cumulative aboveground temperatures increased, while higher solar radiation levels decreased and longer daylengths either increased or decreased vegetative and reproductive components.

In this study, solar radiation, daylength, and aboveground temperature were associated with early flowering. This result agrees with those of Lockshin and Elfving (1981) that high temperatures promote early flowering in 'Heritage', but also suggests that light intensity and daylength may be equally important to flowering. In their review of the interactions between daylength and other environmental factors on flowering, Bernier et al. (1981) list many examples of the interactions between light 
Table 3. Multiple regression equations relating vegetative and reproductive components of three PF red raspberries to seasonal climatic elements. ${ }^{\mathrm{Z}}$

\begin{tabular}{llc}
\hline \hline Climatic & Regression coefficients \\
Yeild & elements & (listed in order of climatic elements)
\end{tabular}

\begin{tabular}{|c|c|c|c|c|c|c|c|c|}
\hline \multirow[b]{2}{*}{ component } & \multirow[b]{2}{*}{ (time interval) } & \multirow[b]{2}{*}{$R^{2}$} & \multirow[b]{2}{*}{$\mathrm{CVs}^{\mathrm{y}}$} & \multirow[b]{2}{*}{$a^{x}$} & & & & \\
\hline & & & & & b1 & b2 & b3 & b4 \\
\hline \multicolumn{9}{|l|}{ Cane ht (cm) } \\
\hline & X1 Soil temp (ApO) & 0.93 & $\mathrm{AB}$ & -5838 & +0.50 & +0.02 & -0.07 & +5.2 \\
\hline & $\mathrm{X} 2$ Water $(\mathrm{ApO})$ & & $\mathbf{H}$ & -7765 & +0.83 & +0.02 & -0.07 & +6.8 \\
\hline & X3 Solar (AgO) & & $\mathbf{R}$ & -6058 & +0.83 & +0.02 & -0.08 & +5.4 \\
\hline & $\mathrm{X} 4$ Daylength (AgO) & & $\mathrm{SE}^{\mathrm{w}}$ & & 0.16 & 0.01 & 0.03 & 1.7 \\
\hline
\end{tabular}

Cane diam $(\mathrm{cm})$

$$
\begin{aligned}
& \text { X1 Soil temp (ApO) } \\
& \text { X2 Water (ApO) } \\
& \text { X3 Daylength (AgO) } \\
& \text { X4 GDD (JnJl) }
\end{aligned}
$$

Node count per cane

X1 Soil temp (JnJl)
X2 Average air temp
$\quad($ AgO)

Full bloom (days after 1 Jan.)

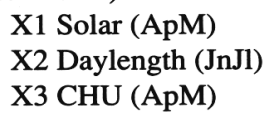

First harvest (days after 1 Jan.)

X1 Soil temp (ApO)
X2 Water (JnJ1)
X3 Solar (ApM)
X5 CHU (ApM)

Flower count per cane

X1 Soil temp (ApO)
X2 Water (ApO)
X3 Solar (JnJ)
X4 CHU (AgO)

Flower count per fruiting lateral

$$
\begin{aligned}
& \text { X1 Soil temp (ApO) } \\
& \text { X2 Solar (JnJl) } \\
& \text { X3 Daylength (JnJl) } \\
& \text { X4 CHU (AgO) }
\end{aligned}
$$

Length of fruiting section

$$
\text { X1 Solar (ApO) }
$$$$
\mathrm{X} 2 \text { Daylength (AgO) }
$$

Fruiting laterals (no.)

X1 Soil temp (ApO)

$\mathrm{X} 2$ Water (AgO)

$\mathrm{X} 3$ Daylength (AgO)

X4 GDD (JnJl)
0.88

$\begin{array}{cc}\mathrm{AB} & +16 \\ \mathrm{H} & +18 \\ \mathrm{R} & +57 \\ \mathrm{SE}^{\mathrm{w}} & \end{array}$

$+0.0006$ $-0.00004$

$-0.0047$

$+0.0002$

$-0.013$

$-0.015$

0.003

$+0.0002$

$+0.0002$

$-0.049$

0.013

$+0.001$

$+0.002$

$+0.002$

0.0007

0.85

$\begin{array}{ccrr}\mathrm{AB} & +31 & -0.31 & +0.38 \\ \mathrm{H} & +36 & -0.39 & +0.52 \\ \mathrm{R} & +48 & -0.53 & +0.35 \\ \mathrm{SE}^{\mathrm{w}} & & 0.33 & 0.21\end{array}$

0.96

$\begin{array}{cc}\mathrm{AB} & +269 \\ \mathrm{H} & +281 \\ \mathrm{R} & +82 \\ \mathrm{SE}^{\mathrm{w}} & \end{array}$

$-0.46$

$-0.10$

$-1.91$

$+0.38$

$-0.25$

0.20

$-0.79$

1.50

$+0.08$

$+0.13$

$+0.085$

0.02

0.92

$\begin{array}{cc}\mathrm{AB} & +107 \\ \mathrm{H} & +181 \\ \mathrm{R} & +155 \\ \mathrm{SE}^{\mathrm{w}} & \end{array}$

$-0.21$

$-0.37$

$+0.025$

$-0.006$

$+0.016$

$+0.003$

$-0.10$

0.25

0.014

$+0.079$

-0.045
0.05

+1.45
+0.46

$+0.99$

0.91

$\begin{array}{cc}\mathrm{AB} & -151 \\ \mathrm{H} & +197 \\ \mathrm{R} & +38\end{array}$

$+3.03$

$+0.06$

$+0.06$

$+0.09$

$+2.85$

1.70

0.04

-0.01
-0.14
-0.15
0.12

$-0.072$

$+0.112$

$-0.014$

0.08

0.88

$\begin{array}{cc}\mathrm{AB} & +201 \\ \mathrm{H} & +198 \\ \mathrm{R} & +187 \\ \mathrm{SE}^{\mathrm{w}} & \end{array}$

+0.13
-0.12
+0.13
0.09

$-0.02$

$-0.19$

$-0.003$

$-0.02$

$-0.17$

$+0.007$

$-0.02 \quad-0.18$

$-0.0007$

$0.0008 \quad 0.05$

0.005

0.44

$\begin{array}{cc}\mathrm{AB} & -3264 \\ \mathrm{H} & -2873\end{array}$

$-0.006$

$-0.002$

$-0.009$

$+2.89$

$+2.53$

$\mathrm{R}$
$\mathrm{SE}$

$-1849$

0.006

$+1.67$

1.10

0.91

$\begin{array}{cc}\mathrm{AB} & -174 \\ \mathrm{H} & +50 \\ \mathrm{R} & +473 \\ \mathrm{SE}^{\mathrm{w}} & \end{array}$

-0.02
-0.03
-0.07
0.05
$+0.002$
$+0.009$
$+0.008$
0.003

$+0.16$

$-0.44$

$-0.40$

$+0.01$

$+0.02$

$0.31+0.01$

continued. 
Table 3. continued.

\begin{tabular}{|c|c|c|c|c|c|c|c|c|c|}
\hline \multirow{2}{*}{$\begin{array}{l}\text { Yeild } \\
\text { component }\end{array}$} & \multirow{2}{*}{$\begin{array}{c}\text { Climatic } \\
\text { elements } \\
\text { (time interval) }\end{array}$} & \multirow[b]{2}{*}{$R^{2}$} & \multirow[b]{2}{*}{$\mathrm{CVs}^{\mathrm{y}}$} & \multirow[b]{2}{*}{$a^{x}$} & \multicolumn{5}{|c|}{$\begin{array}{c}\text { Regression coefficients } \\
\text { (listed in order of climatic elements) }\end{array}$} \\
\hline & & & & & b1 & b2 & b3 & $\mathrm{b} 4$ & b5 \\
\hline \multirow[t]{4}{*}{ Harvest period } & X1 Water (JnJl) & 0.77 & $\mathrm{AB}$ & +213 & -0.01 & -0.18 & +1.76 & & \\
\hline & X2 Solar (AgO) & & $\mathrm{H}$ & +127 & +0.03 & -0.13 & +1.76 & & \\
\hline & X3 Average air temp & & $\mathbf{R}$ & +63 & +0.01 & -0.08 & +2.00 & & \\
\hline & $(\mathrm{AgO})$ & & $\mathrm{SE}^{\mathrm{w}}$ & & 0.015 & 0.07 & 0.55 & & \\
\hline
\end{tabular}

${ }^{\mathrm{z}} \mathrm{ApO}=$ April through October; ApM = April and May; JnJl = June and July; AgO = August through October.

${ }^{\mathrm{y}} \mathrm{AB}=$ 'Autumn Bliss', $\mathrm{H}=$ 'Heritage, and $\mathrm{R}=$ 'Redwing' $\mathrm{PF}$ red raspberry cultivars.

'Intercept has no biological significance. It is the point where all climatic variables are set to 0 . It is only useful in calculating predicted yield component values. Values for $\mathrm{b} 1, \mathrm{~b} 2, \mathrm{~b} 3, \mathrm{~b} 4$, and $\mathrm{b} 5$ are the regression coefficients for the $\mathrm{X} 1, \mathrm{X} 2, \mathrm{X} 3, \mathrm{X} 4$, and $\mathrm{X} 5$ climatic elements.

$w_{S E}$ is the average standard error of regression coefficients for the three cultivars.

duration and light intensity. One mechanism whereby light intensity and duration may influence flowering is through net $\mathrm{C}$ gain. When roses (Rosa hybrida, 'Samantha') were exposed to the same daily radiant energy dose provided either as a 12 -h $(410$ $\left.\mu \mathrm{mol} \cdot \mathrm{m}^{-2} \cdot \mathrm{s}^{-1}\right)$ or $24-\mathrm{h}\left(204 \mu \mathrm{mol} \cdot \mathrm{m}^{-2} \cdot \mathrm{s}^{-1}\right)$ PAR, an $80 \%$ increase in retained $\mathrm{C}$ was observed for the plants exposed to $24 \mathrm{~h}$ of continuous irradiation at the lower photon flux density (Jiao et al., 1991). Concomitantly, plants that had higher daily $\mathrm{C}$ gain flowered earlier (Jiao, 1989). The effect of light intensity and duration on wholeplant $\mathrm{C}$ gain is poorly defined in $\mathrm{PF}$ red raspberries.

The climatic variables may also have had an indirect effect on the fruitfulness of the canes, since cane diameter has been associated with carbohydrate supply (Crandall et al., 1974). Accordingly, Privé et al. (1993) reported that the location with the largest cane diameters also had the largest yields. The climatic elements most affecting cane diameter were daylength, water, soil, and air temperatures. 'Redwing' appeared to be the most sensitive of the three cultivars because cane diameters decreased the most in response to higher soil temperatures and longer daylengths.

The climatic elements that most influenced flower count per lateral and number of fruiting laterals were daylength, soil, and air temperatures, and either solar radiation for flower count per lateral or water supply for number of fruiting laterals. 'Heritage' was the anomaly among the three cultivars. Areas with higher air temperatures during August to October resulted in a positive increase in flower count per lateral for 'Heritage' but had little influence on 'Autumn Bliss' or 'Redwing', two earlier maturing cultivars. Due to the late maturing habit of 'Heritage', warmer temperatures during this period had a greater impact on its ontogenetic development and its ability to achieve maximum yield potential.

Together, CHU, amount of solarradiation, water, and daylength from April to May were most important in influencing the date of first harvest. As with soil temperatures, this suggests that cultural practices that can optimize some of the climatic elements early in the season may prove to be important for optimizing growth and development of PF red raspberries in north temperate areas. Hoover et al. (1989) found that the differences between cultivar harvest dates could not be explained simply by differences in heat unit accumulation (GDD) or latitude, i.e., daylength, when summed over the entire growing season. Our study confirms that measurements such as GDD, CHU, or average air temperature when summed over the growing season were not associated with any of

Table 4. Multiple regression equations relating yield components of three PF red raspberries to seasonal climatic elements. ${ }^{\mathrm{z}}$

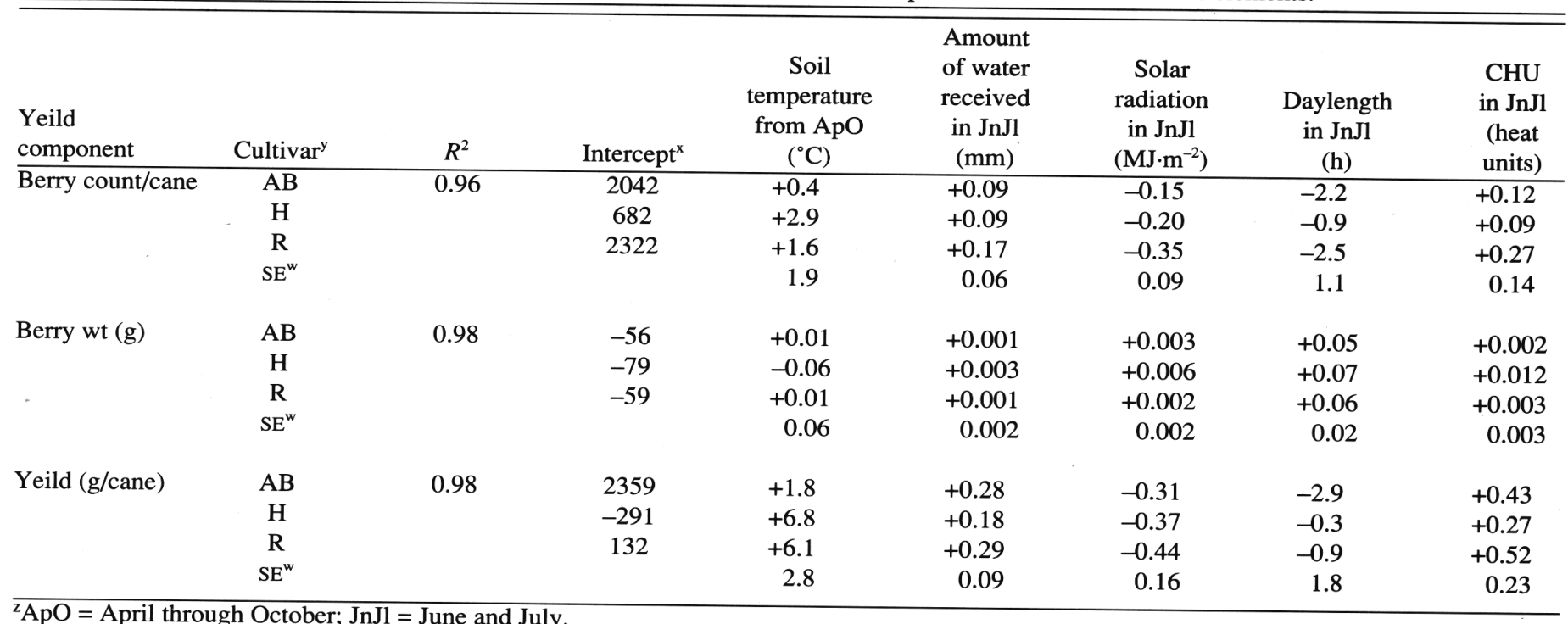

y $\mathrm{AB}=$ 'Autumn Bliss'; $\mathrm{H}=$ 'Heritage'; $\mathrm{R}=$ 'Redwing'

'Intercept has no biological significance. It is the point where all climatic variables are set to 0 . It is only useful in calculating predicted yield component values.

${ }^{w_{S E}}$ is the average standard error of regression coefficients for the three cultivars. 
the vegetative or reproductive components measured. The influence of air temperature is lost when temperatures are cumulated over the season because each stage of development responds more to short- rather than long-term climatic effects. Privé et al. (1993) found that although the climatic conditions during the course of their study differed significantly, it was not obvious by looking at the seasonal totals. However, the present study found significant associations between the vegetative and reproductive components and the aboveground temperature elements for particular calendar intervals during the growing season. Aboveground temperatures from June to July positively influenced the greatest number of these components, which seems logical since this interval approximates the time of flower bud initiation. Cultivar $\mathbf{x}$ aboveground temperature interactions were found for total number of flowers, number of fruiting laterals, berry count and weight and, consequently, yield. This interaction was most apparent in 'Heritage' because it was the latest of the three cultivars to reach reproductive maturity. In the future, a breakdown of the growing season by phenological intervals rather than by calendar intervals may provide additional information as to how temperature influences growth and development of PF red raspberries.

In summary, climatic elements were able to account for some of the variability in the yield trials, with soil temperature and available water as the two most influential elements. These results suggest that in a north temperate climate, growth and development of PF red raspberries could be optimized if soil temperatures could be increased in early spring and moderated during the midseason. Floating row covers, applied in early spring, show promise in increasing soil temperatures during the early stages of growth (Pritts et al., 1992), while the well documented use of mulch could modify the extreme soil temperatures during the midseason (Clark, 1940). This study provides some insight into which climatic elements influence growth and development of PF red raspberries in north temperate regions.

\section{Literature Cited}

Atkinson, D. 1973. Seasonal changes in the length of white unsuberized root on raspberry plants grown under irrigated conditions. J. Hort. Sci. 48:413-419.

Bernier, G., J.M. Kinet, and R.M. Sachs. 1981. The physiology of flowering. vol. 1. The initiation of flowers. CRC Press, Boca Raton, Fla. Brown, D.M. 1978. Heat units for corn in southern Ontario. Factsheet, AGDEX 111/31. Ont. Ministry Agr. Food, Toronto, Ont.

Clark, J.H. 1940. The effects of mulching red raspberries on growth and production. Proc. Amer. Soc. Hort. Sci. 37:604-608.
Crandall, P.C., J.D. Chamberlain, and K.A. Biderbost. 1974. Cane characteristics associated with berry number of red raspberry. J. Amer. Soc. Hort. Sci. 99:370-372.

Dale, A. 1986. Some effects of the environment on red raspberry cultivars. Acta Hort. 183:155-162.

Dale, A. 1989. Productivity in red raspberries. Hort. Rev. 11:185-228.

Dale, A. and H.A. Daubeny. 1985. Genotype-environment interactions involving British and Pacific Northwest red raspberry cultivars. HortScience 20:68-69.

Erf, J. 1987. Cropping and environmental effects on incremental vegetative growth of apple. PhD Diss., Univ. of Guelph, Guelph, Ont.

Goode, J.E. and K.J. Hyrycz. 1968. The response of malling jewel and malling exploit raspberries to different soil moisture conditions and straw mulching. J. Hort. Sci. 43:215-230.

Hoover, E., J. Luby, D.S. Bedford, M. Pritts, E. Hanson, A. Dale, and H. Daubeny. 1989. Temperature influence of harvest date and cane development of primocane-fruiting red raspberries. Acta Hort. 262:297-303.

Jennings, D.L, and A. Dale. 1982. Variation in the growth habit of red raspberries with particular reference to cane height and node production. J. Hort. Sci. 57:197-204.

Jiao, J. 1989. Predicting the growth response of greenhouse roses to aerial environments based on $\mathrm{CO}_{2}$ exchange studies. PhD Diss., Univ. of Guelph, Guelph, Ont.

Jiao, J., M. Gilmour, M.J. Tsujita, and B. Grodzinski. 1991. Influence of radiation and $\mathrm{CO}_{2}$ enrichment on Whole plant net $\mathrm{CO}_{2}$ exchange in roses. Can. J. Plant Sci. 71:245-252.

Keep, E. 1988. Primocane (autumn)-fruiting raspberries: A review with particular reference to progress in breeding. J. Hort. Sci. 63:1-18.

Kinet, J.M., R.M. Sachs, and G. Bernier. 1985. The physiology of flowermg. vol. III. The development of flowers. CRC Press, Boca Raton, Fla.

Kongsrud, K.L. 1969. Vatningsforsk med bringebaer (Irrigation experiments with raspberries). Forskning og Fors $\varnothing$ ki Landbruket 20:435-446.

Lockshin, L.S. and D.C. Elfving. 1981. Flowering response of 'Heritage' red raspberry to temperature and nitrogen. HortScience 16:527-528.

Pritts, M., E. Hanson, J. Fiola, and M.J. Kelly. 1992. Rowcovers accelerate fruiting and increase productivity in primocane-fruiting red raspberries. HortTechnology 2:46-51.

Privé, J.-P., J.A. Sullivan, J.T.A. Proctor, and O.B. Allen. 1993. Performance of three primocane-fruiting red raspberry cultivars in Ontario and Québec. 118:388-392.

Rajappan, P.V. and D. Boynton. 1960. Responses of black and red raspberry root systems to different oxygen and carbon dioxide pressures at two temperatures. Proc. Amer. Soc. Hort. Sci. 75:402-406.

SAS Institute. 1987. SAS/STAT guide for personal computers. version 6 (ed.). SAS Institute, Cary, N.C.

Selirio, I.S., D.M. Brown, and K.M. King. 1971. Estimation of net and solar radiation. Can. J. Plant Sci. 5 1:35-39.

Voroncihina, Z.N. 1967. The root system of raspberries (in Russian). Akad. K.A. Timirjazeva 132:55-59. 